\title{
The Science of Athletics
}

\section{What Is It That Distinguishes the Star from the Mediocre Performer?}

\author{
By Charles W. Paddock, Olympic Champion, 100 Meters
}

T HERE are two characteristics which go to make an athlete, muscular development and nervous energy.
It makes no difference how many other qualificaIt makes no difference how many other qualifica-
tions a man may have, if he does not possess both of tions a man may have, if he does not possess both of these in at least some small degree, he will

A man who already possesses natural physical strength has a distinct advantage over the man who is forced to develop it through a course of rigorous training. Because the man who is a born athlete, if he spends an equal amount of time in training himself, will become a super-athlete, and a champion. However, it is not impossible for a man to become a great athlete, even though he be handicapped by a poor physique in the beginning. Indeed, some of our greatest performers today are men who do not have the appearance of athletes, and yet possess an uncanny degree of strength in certain fields of physical endeavor. Richmond W. Landon of Yale University, Olympic Champion in the high jump does not have the appearance of an athlete, yet he has so developed himself as to have a greater amount of spring in his legs, than any other jumper in the world. Morning, noon and night he skipped rope, jumped for imaginary apples, hung high on imaginary branches, until it became with him a habit to jump. Then when he first attempted leaping the high jump bar he wore heavy shoes and clothing, and when at last he was able to clear high heights in such garb, he donned a track suit and spikes, which gave him the lightsome feeling that so impresses the spectator who watches this slim, unathletic looking person clear heights which natural-born athletes dare not attempt. . . B But in golf and tennis, and more particularly in running, nervous energy is more important than muscular development. Its a question of nerves more than strength to sink a tennerves more than strength to sink a tenfoot put, when it means the match, or to avoid serving doubles in the game that means the set, or to get off with the field, in a short distance race

There was a great sprinter in this country, recently retired, who was the fastest man from the mark among the great indoor track competitors. His perception of the starting pistol report. was so lightning-fast that his muscles seemed to react to the sound of the gun, without any mental command on his own part. On the ordinary man who should start beside him he would probably have gained ten yards in the first twenty, while against ten yards in the first twenty, while against
the average track man he would easily the average track man he would easily
gain two yards in that distance, and even the greatest opponents conceded two feet to his start because of that marvelous reaction of his. But this little fellow, Jackson V. Sholtz of the University of Missouri, had worked long and hard to gain this advantäge. And it was not only the result of physical effort and practice, but was also due to the training to effort and practice, but was also due

And herein lies the hope for the man of business of keen brain and unresponsive muscles. He can train himself even as Sholtz and Landon have done, to such a physical state that his muscles will react to his will, and though he may never have the strength of a Ralph Rose or the speed of a Jack Sholtz or the spring of a Dick Landon, yet he will have enough of that muscular development to pair with his nervous energy which he development to pair with his nervous energ

It has been said that a man cannot begin late in life to play any game and become a champion. But there is not very much to that theory. It has been upset too many times. It might apply to the grayhaired veteran who attempted to run a race or play football, but even then there have been so many exceptions the rule can hardly stand. Some of our greatest athletes never began until late in life, and not greatest athletes never began until late in life, and not all our baseball players were born with the rawhide
sphere in their hands. As for golf any man if he is physically fit, or can make himself so, can by practice become a 90 per cent man, and with sufficient handicap can win tournaments.

This training to become a champion does not take all of your time. Indeed, it consumes just enough to give a man the essential recreation which he needs for give a man the essential recreation which he needs for
che pursuit of health. It can be engaged in so as to

benefit business as well as physique, and when the practice days are past, you will have the satisfaction of feeling that you can conquer in competitive sport, which is one of the most satisfying of feelings.

The old theory used to be that in order to attain success in athletics a man could do nothing else but prepare himself for his own particular event to the exclusion of any other work. That idea does hold good, in that a man can really be a champion in only one athletic endeavor at a time. This is the age of specialization, no doubt of it, and if a man will take up one event and religiously perfect himself in it, he will certainly succeed. Of course there are a select few who can do a number of athletic feats well, and a few who have become stars in two or three different fields. Many college men become proficient in both football and track, but there are very few who become champions in more than one kind of competitive sport. champions in more than one kind of competitive sport.
The victory of Miss Mary Browne of California in the southern California Golf Championships coupled with her brilliant career in the world of tennis makes of her one of the most notable exceptions to the rule. But outside of specialization the theory that a man can do nothing else but athletics, if he is an athlete is incorrect. Indeed, athletics is similar to business in that the star performers in each field must have relaxation in the other in order to be at their best.

For several years the writer has been engaged in newspaper work and college studies and at the same time has been doing track work. The two have gone hand in hand, and each has been benefited by the other. Because of that need for relaxation, athletics was first taken up. In order to create a definite inter-

should be engaged in prior to a contest of course depends upon the amount of playing that has been done by the individual. For example if it were track, and the man had run several seasons, in high school and college competition, a couple of weeks' running and a week devoted to starting practice would be about all that was necessary, providing always the contestant was already in good physical condition.

If the athlete had never competed in that form of athletics before, or indeed had never taken an active part in any kind of competition, there are several methods of enjoyable exercise which should prove strengthening, particularly if the form of sport contemplated was of a strenuous nature. There is nothing which will develop a boy or young man so quickly or so well as swimming. Bicycle riding, too, if not walking, along with either of these, furnishes a combination of muscular development hard to surpass. But if swimming is the form of sport the neophyte desired to perfect himself in, then a great deal of running would prove profitable. In the first place it is the direct opposite of swimming and develops an entirely different set of muscles. So that when the runner becomes a swimmer he can tell the progress he is making by the swimmer he can tell the progress he is making by the
degree of soreness which he experiences. This soreness of course indicates that other muscles are being developed, and unless you swim a very great deal which is not good at first, then it will take you a much longer time to develop your muscles. Again, in swimming, it's your chest and shoulders and arm muscles which receive the most attention, and by running you have also developed leg muscles as well. When you become a champion, that extra development which the pion, that extra development which the
running gave you, will give you an advantage over the great swimmer, who never ran. And so the theory holds true in many kinds of competitive sport. Though you may specialize in only one, you may gain a great deal of assistance from the participation in other kinds of athletics.

Joie W. Ray, considered by many the greatest mile runner who ever lived, wins greatest mile runner who ever lived, wins
his races simply because he had development in another kind of sport before he became a long distance runner. Ray boxed a great deal when a boy, and developed a marvelous chest and lung capacity. $\mathrm{He}$ also had a splendid pair of legs.

The mile-race, as you know, is usually run on a quarter-mile track, and after the runners have circled the oval twice, Ray runners have circled the oval twice, Ray
starts his sprint All other milers wait until the fourth lap to begin running their hardest. So when they meet Ray, and he

est in daily exercise, one particular event was chosen, and it was made a specialty with the result that the real business of life was improved, and at the same time a new pleasure was created by watching the improvement of my work on the track.

The only difference between my training and that of any other athlete is the fact that within a week's notice, providing of course I have not been the victim of some illness, I could make myself ready to enter my hardest competition with every confidence of being at my best. That is the greatest pleasure of athletics, having the feeling that I am physically fit. So often athletes have found themselves in the worst possible physical condition within a few days after strenuous competition, because they have suffered reaction from training and gone to the other extreme of dissipation. But if a man pursue a moderate course and keeps himself in good condition at all times he will not have to train so strenuously just before a great contest, and therefore will not feel the need of breaking training immediately the ordeal is over.

In order that a man may not become weary of the particular sport wherein he is most adept, it is a good idea to engage in some other exercise part of the time, and only train in that certain field of athletics a few weeks before competition. For the first thing essential to success will be condition, physical condition. It makes no difference what manner of exercise you have taken so long. as you are fit for the contest.

After gaining your condition, and by that I mean feeling strong and well, having strength and pep, and being able to engage in hard work in the daytime and sleeping well at night, the amount of practice which runs away from them in the third lap, they don't know what course to pursue. If they attempt to stay with him they may hold him for that lap, but when the fourth and last quarter is reached they have run their race, while the great reserve that Ray has gained from boxing enables him to fight it through to the end. On the other hand if the milers pursue their usual tactics, and wait until the fourth lap to sprint, though they may gain on him, Ray is so far ahead that they never can catch him.

Though boxing may help you in running, and running in swimming, and swimming in tennis, etc., the essential stuff of which champions are molded is confidence. It is produced by nervous energy and the belief that you surely can do the thing you set out to accomplish

The right mental attitude is after all the most important part about athletics. Belief in yourself and in your own ability is certainly one of the foremost stepping stones to athletic success. If you have nervou energy and plenty of it, and a firm belief in yourself, you can develop the necessary muscles through practice in different forms of exercise to become a star in almost any branch of competitive sport for which you are fitted.

And it is not a question of eternal playing either. If within a few months you show no signs of improvement, then change to another kind of athletic activity, there are plenty of them, and keep changing until you do find yourself. Then stick to it, and if you get out only once a week, at least practice a little bit at home in the morning before business, or in the evening, when the day's work is done. 